\title{
Connecting Society and Policymakers? Conceptualizing and Measuring the Capacity of Civil Society Organizations to Act as Transmission Belts
}

\author{
Adrià Albareda ${ }^{1}$
}

Published online: 5 November 2018

(C) The Author(s) 2018

\begin{abstract}
Civil Society Organizations (CSOs) are considered important intermediaries between citizens and policymakers. They are assumed to function as transmission belts that filter societal preferences and channel them to policymakers. Although the ability of CSOs to connect civil society with policymakers has been put into question, it has rarely been theoretically specified and empirically tested. This paper develops a conceptualization of CSOs that examines their capacity to function as transmission belts. It does so by distinguishing two organizational dimensions related to member involvement and organizational capacity. The paper draws on a large survey of CSOs active at the EU to empirically assess these organizational dimensions and relate them to basic CSOs' characteristics. The findings indicate that one out of three organizations approximates the ideal-type transmission belt. The findings contribute to a better understanding and assessment of CSO's potential contribution to policy-making in representative democracies.
\end{abstract}

Keywords Civil Society Organizations · Democracy · Transmission belt - Member involvement - Organizational capacity

Adrià Albareda

a.albareda@fgga.leidenuniv.nl

1 Institute of Public Administration, Leiden University, Turfmarkt 99, 2511-DP The Hague, The Netherlands

\section{Introduction}

Civil Society Organizations (CSOs) are crucial intermediary organizations that connect citizens with policymakers (Easton 1971; Putnam 1993; Rasmussen et al. 2014; Truman 1951). By acting as transmission belts between the preferences of civil society and the actions of policymakers, CSOs can supplement the deficiencies of public institutions and contribute to a well-functioning democracy, promoting the legitimacy and effectiveness of governance systems (Greenwood 2007; Kohler-Koch 2010). Yet, as several studies have indicated, the representative function of many CSOs is severely flawed (Binderkrantz 2009; Halpin 2006; Jordan and Maloney 2007; Kohler-Koch 2010). And even when CSOs successfully involve their membership base to ensure representativeness, they may lack the organizational capacity that facilitates an effective interaction with policymakers (Schmitter and Streeck 1999; van der Pijl and Sminia 2004).

The idea that CSOs function as transmission belts denotes, although often implicitly, that they are able to aggregate member preferences and efficiently transfer these to policymakers. To date, and despite the burgeoning literature on CSOs and interest groups in general, there is little understanding of how well CSOs manage this balancing act. The main reason for this gap in the literature is that scholarly work has usually emphasized just one of the constituting elements of the transmission belt. Studies focus either on membership involvement (Binderkrantz 2009; Jordan and Maloney 1998; Kohler-Koch 2010; Moe 1991), or on the organizational capacities developed to be more professionalized (Klüver 2012; Klüver and Saurugger 2013; Maloney 2015; Skocpol 2003), but not on how CSOs can and do manage the combination of these two aspects. Furthermore, most studies use indirect variables and 
proxies to assess CSO membership involvement and organizational capacity-the most frequent ones being resources, organizational type (citizen vs. business groups), scope of action (specialist vs. generalist organizations), and organizational scale (individual organizations, national associations, or supranational associations)-thereby obscuring key organizational processes that facilitate the connection between society and policymakers. We thus do not have a clear understanding of how organizational processes can contribute to a genuine transmission belt function of CSOs, a function that is often assumed or required by public institutions. This is problematic as it results in limited knowledge of the role of CSOs in representative democracies and hinders a good understanding of how public institutions might involve them in a more effective way.

This paper aims to fill this gap by unpacking the organizational structure of CSOs and examining how it relates to fulfilling a transmission belt role. By focusing on the internal structure of CSOs, the paper builds upon recent work that has highlighted the importance of organizational factors for connecting CSOs with their members and transferring their demands to policymakers (Albareda and Braun, forthcoming; Berkhout 2013; Binderkrantz 2009; Braun 2013, 2015; Fraussen and Beyers 2016; Fraussen et al. 2015; Halpin 2014; Halpin et al. 2018; Klüver 2012; Minkoff et al. 2008; Muñoz Marquez 2016; Naoi and Krauss 2009). Drawing on these studies in conjunction with organizational theory, the paper conceptualizes the transmission belt function by distinguishing two organizational dimensions directly related to the two audiences with whom CSOs mostly interact: members and policymakers (Ainsworth and Sened 1993). Importantly, involving members and having organizational capacity to be politically active may lead to organizational tensions (Maloney and Saurugger 2014; Schmitter and Streeck 1999; van der Pijl and Sminia 2004), hindering CSOs' capacity to function as transmission belts. However, there is limited evidence on whether this trade-off in fact exists. This paper draws on a large survey of CSOs active at the European Union (EU) level to test the occurrence of the two organizational dimensions and, hence, the capacity of CSOs to relay members' preferences to policymakers (Kohler-Koch 2010; Schmitter and Streeck 1999; van der Pijl and Sminia 2004). In other words, this paper examines CSOs by focusing on their organizational structure, which reflects member involvement (i.e., internal democratic structures) and organizational capacity (i.e., features aimed at efficiently generating, processing, and transferring information to policymakers). The focus on these organizational dimensions enables us to assess how much organizational variety exists among CSOs and how many of them are effectively organized as transmission belts. The paper shows that one out of every three CSOs at the EU level is effectively organized as a transmission belt as they invest in structures to foster representativeness of their members and, simultaneously, have the features that facilitate an effective interaction with policymakers. Yet, the majority of CSOs do not invest in both organizational dimensions at the same time and, thus, do not have the same potential contribution to a legitimate and effective EU governance.

\section{Unpacking the Transmission Belt: Dimensions of Organizational Structure}

Any organization has to design a formal structure to effectively implement a strategy and reach their goals (Chandler 1962). CSOs are no exception. Defined in its broader sense, the term CSO includes organizations representing social and economic players (e.g., trade unions, employers' federations, consumer organizations and nongovernmental organizations), organizations that bring people together in a common cause (e.g., environmental organizations and human rights groups), and organizations pursuing member-oriented objectives (e.g., youth organizations and family associations) (European Commission 2002, p. 6). As such, CSOs are complex entities that require certain organizational structures to reach their objectives. Thus, when CSOs are formed, the leadership together with members and other key stakeholders needs to respond to the inescapable question of 'how should we organize' (Halpin 2014, p. 85). From a functionalist approach, the organizational structure of CSOs is aimed at solving collective action problems and achieving desired outcomes for their membership base as effectively and efficiently as possible (Williamson 1981). In this perspective, the main assumption is that the organizational structure ' $\mathrm{X}$ ' is an instrument for achieving calculable and predictable control of organizational performance, and thus, it serves function ' $\mathrm{Y}$ ' (Pierson 2000, p. 476). Accordingly, the organizational structure of CSOs can be conceived as a driver for the successful formulation and implementation of strategies, and thus, for achieving organizational goals (Greenwood and Miller 2010).

As intermediary organizations that relay constituents' demands to policymakers, CSOs that intend to act as transmission belts require organizational attributes that enhance their ability to speak and interact with their two main audiences: members and policymakers ${ }^{1}$ (Ainsworth

\footnotetext{
${ }^{1}$ Policymakers are those public officials (elected or unelected) responsible for formulating policies (Beyers and Braun 2014). Hence, policymakers include actors ranging from governmental elites or top politicians to lay civil servants. At the EU level, policymakers as defined here are found in the three main EU institutions (Commission, Parliament, and Council).
} 
and Sened 1993). In their seminal article, Schmitter and Streeck (1999, p. 19) note that CSOs have to, on the one hand, 'structure themselves and act so as to offer sufficient incentives to their members to extract from them adequate resources to ensure their survival, if not growth. On the other hand, they must be organized in such a way as to offer sufficient incentives to enable them to gain access to and exercise adequate influence over public authorities.' Hence, CSOs aiming to operate as transmission belts have to ensure that their work is well received by both their members and policymakers (Jordan and Maloney 2007) and, consequently, set up adequate organizational structures to fulfill these objectives. Specifically, CSOs require organizational features that facilitate the alignment of preferences with their members (Kohler-Koch 2010), but also the structures that enable them to efficiently generate, process, and transfer valuable resources to policymakers. To examine the extent to which CSOs are organized as transmission belts, the paper builds upon an organizational configuration approach (cf., Miller 1996; Mintzberg 1979; Short et al. 2008). This approach enables to depict common patterns across CSOs and develop typologies of organizations that resemble each other along the critical organizational dimensions identified to accomplish the transmission belt function: member involvement and organizational capacity.

\section{Member Involvement}

Members are the inner core of CSOs' constituency. As such, membership involvement is essential to derive legitimacy for their advocacy and lobbying activities by claiming broad representativeness (Johansson and Lee 2014, p. 405). When policymakers seek to increase input legitimacy through stakeholder involvement, representative CSOs are expected to be better positioned to make their voice heard. Being attentive to members' preferences is also important for maintenance and survival of organizations (Wilson 1995), in particular for those whose budget highly relies on membership fees. Moreover, involving the membership base, and thus being responsive toward their demands, is a critical internal element that shapes the identity of the organization (Heaney 2004) and the issues prioritized in the policy agenda of the organization (Halpin et al. 2018).

Despite these inducements to actively involve members, previous work has demonstrated that CSOs engage with members to different degrees and that organizations have different representation strategies (Johansson and Lee 2014). Some CSOs are structured to actively involve their members, gather their opinions and preferences, and act accordingly. In contrast, other CSOs have a managerialist discourse and work as professionalized oligarchies where the senior staff has the autonomy and discretion to take every relevant decision without consulting with a largely passive membership base that is weakly involved in the internal functioning of the organization (Jordan and Maloney 2007; Maier and Meyer 2011).

There is a large variety of tools and methods to involve members (e.g., consultation mechanisms, internal surveys, plenary and ad hoc meetings, and involvement of members in executive bodies and working groups); yet, as shown by Johansson and Lee (2014), CSOs rely heavily on formal structures to involve their members in the internal functioning. In this vein, this paper conceptualizes member involvement with three crucial formal elements that enable CSOs to collect and aggregate members' preferences and become representative organizations; these are: the processes set up to facilitate interaction among members and CSOs representatives (Hayes 1986); the decision-making system (Berry 1984); and the formal connections between the organization and its local/regional constituency (Skocpol 2003).

Firstly, providing a forum where members can interact among themselves and with representatives of the CSO is conceived as crucial to facilitate member involvement (Hayes 1986; McFarland 2010, p. 55). As highlighted by Jordan and Maloney (2007, p. 2), CSOs should 'offer opportunities for face interaction to enhance social integration and democracy itself.' Besides, the interaction among members is an occasion to develop quality relationships, foster the cohesion of the organization, and promote a more homogenous message across members. As specified by Albers et al. (2013), the relationship derived from the interaction of members cultivates ties, supports the development of trust in the organization, and strengthens the flow of information among members and between members and the organization.

Secondly, the decision-making system determines the actual power of members to establish positions and strategies (Albareda and Braun forthcoming; Berry 1984; Binderkrantz 2009; Halpin and Fraussen 2017; Hollman 2017). CSOs can be subject to the preferences of their members or, instead, may delegate the decision-making power to the executive board, the leader of the organization, or to senior staff. When decisions are taken by members, it means that these actors have strong powers to determine the avenues of the organization. Using Berry et al.'s (1993) terms, decision-making systems are about the depth of participation of members in a group. More generally, engaging members in decision making is a way to internalize conflict and, as a consequence, the likelihood that members take individual steps to circumvent the organization is reduced (Hollman 2017).

Finally, the organizational structures set to reach the local constituency of the CSO ease the engagement of members that are not based in the same location as the headquarters of the organization and strengthen the societal 
embeddedness of the organization (Fraussen et al. 2015; Skocpol 2003). Having local branches ensures that the long chain of representation of multilayered CSOs is not broken (Johansson and Lee 2014; Kohler-Koch 2012, p. 818). That is, CSOs with local branches are expected to have closer connections to the membership base and empower the grassroots, thus facilitating the involvement of every member. Making a parallel with the political party literature, local branches constitute the most tightly knit connection between CSO representatives and their constituency (Poguntke 2002, p. 9).

\section{Organizational Capacity}

Apart from involving their members, CSOs intending to function as transmission belts also aim to gain access to policymakers and shape public policy. Consequently, it is necessary to assess the organizational capacity, that is, an organization's potential to achieve its mission and objectives (Eisinger 2002). For a CSO that aims to operate as a transmission belt, organizational capacity refers to those organizational features that enable them to efficiently generate, process, and transfer information from members to policymakers (Daugbjerg et al. 2018; Schmitter and Streeck 1999). More specifically, organizations need to go beyond loose and network-type organizational arrangements and become more formalized entities with autonomy, hierarchical structures, and certain levels of specialization (Schmitter and Streeck 1999).

Recent studies have empirically shown that there is an increasing trend toward the professionalization of CSOs (Klüver and Saurugger 2013; Maloney 2015; Skocpol 2003). The conceptualization of organizational capacity highly relies and speaks to the idea of professionalization, in particular to having the expertise to generate technical knowledge and centralized governance structures pursuing a technocratic and scientific approach to organizational maintenance and influence (Maloney 2015). However, in contrast to the literature on professionalization (Klüver and Saurugger 2013; Maloney 2015), this paper assumes that organizational capacity is compatible with having active membership, which is indispensable to attain the transmission belt ideal. ${ }^{2}$

Importantly, not all CSOs have the organizational attributes that are expected to foster organizational capacity. Whereas organizations like Friends of the Earth or

\footnotetext{
$\overline{2}$ Organizational capacity has also received significant attention in the nonprofit literature. However, this literature is mostly interested in those capacities that facilitate an effective provision/administration of community services in different sectors (Eisinger, 2002; Fredericksen \& London, 2000; Misener \& Doherty, 2009), and not so much on the organizational attributes that endow CSOs with a higher capacity to interact with policymakers.
}

Greenpeace have autonomous and centralized structures and generate cutting-edge expertise, professional associations of lawyers or doctors are more focused on exchanging information and on determining professional standards and good practices. As can be inferred from the previous discussion, CSOs that want to increase their likelihood of shaping public policy require three organizational elements that determine their capacity to efficiently generate, process, and transfer information to policymakers. These organizational features are: autonomy (Verhoest et al. 2004), centralization (Christensen et al. 2016), and functional differentiation (Pugh et al. 1968).

Autonomy is understood as the delegation of discretionary authority to the secretariat, the office, or the senior leadership of the organization (cf., King et al. 2010). An autonomous CSO has the delegated power from its members to act on their behalf. This paper focuses on de facto and operational autonomy, which comprises the actual decision-making competences of CSOs with regard to specific subject matter (Bach 2014, p. 345). This type of autonomy enhances managerial flexibility, contributes to better services, and fosters organizational efficiency (Pollitt et al. 2004). In this vein, autonomy enables the organization to rapidly react to specific events or changing policy environments and, subsequently, it is expected to increase the efficiency in which CSOs process and transfer information to policymakers.

Secondly, CSOs' centralization is understood as the hierarchical integration that serves as a mechanism to coordinate the vertical and horizontal specialization of an organization (Christensen et al. 2016). In centralized CSOs, the apex of the organization (i.e., top representatives) has significant formal and informal power to control the decisions and activities of the organization. In contrast, in a decentralized CSO, mid-managers in charge of departments or committees are expected to have considerable leeway when taking and implementing decisions and to be loosely connected among themselves and with the apex of the organization (Damanpour 1991). Through centralization, CSOs can minimize internal conflict, overcome 'silothinking', feed the different units of the organization, and produce valuable information that goes beyond particular niches (Young 1992). Centralized CSOs not only ensure unity of command and coordination, safeguarding a smooth transmission of member preferences to policymakers, they also favor the accumulation and exchange of information and knowledge produced by the different units and branches of a CSO (Caimo and Lomi 2015).

Lastly, functional differentiation refers to the development of organizational units or committees that deal with concrete policy issues (Klüver 2012). It is defined as the division of labor within an organization and the distribution of official duties among several positions (Pugh et al. 1968: 
72-3). Organizational scholars also refer to this feature as horizontal specialization or complexity, which measures the number of different occupational specialties or specialized units at a given hierarchical level (Fioretti and Bauke 2004). Functional differentiation might be understood as an organizational element that processes the preferences of members and produces specialized knowledge that, ultimately, can be used to generate valuable information for policymakers. In this vein, being functionally differentiated is an organizational mechanism to internalize interdependencies and generate research capacity (Fraussen and Halpin 2017).

\section{Transmission Belts: A Balancing Act Between Member Involvement and Organizational Capacity}

As discussed earlier, the combination of the two dimensions (i.e., member involvement and organizational capacity) is crucial for CSOs to forge a transmission belt capacity. Ideally, a genuine transmission belt requires both involving members and having organizational capacity, and therefore CSOs need to have most of the items in each of these two organizational dimensions. Yet, this is a complex organizational endeavor and, as highlighted by Kohler-Koch (2012, p. 815), it is not clear whether and how CSOs 'manage to reconcile the contradictory demands of effective lobbying and boosting democratic participation.' This twofold objective 'puts substantial organizational demands on groups' (Berkhout et al. 2017, p. 1126), and, as noted by van der Pijl and Sminia (2004), may lead to organizational dilemmas that CSOs need to solve (cf., Schmitter and Streeck 1999). That is, CSOs struggle to find a balance between engaging their members in democratic structures while being politically active in an efficient manner.

Indeed, some of the objectives linked to the organizational items presented above might be difficult to combine. At a general level, these two organizational dimensions reflect two somewhat contradictory approaches: one bottom-up-emphasizing the heterogeneity of members and the need to represent every single voice within the organization-and the other one top-down-emphasizing homogeneity and the need to control members (van der Pijl and Sminia 2004). Fostering member involvement may lead to the inclusion of different voices present in the organization and strengthen its representativeness character, but it is also linked to cumbersome consultations processes that hamper the capacity of CSOs to efficiently respond to policy demands in changing environments (Hollman 2017). In contrast, centralized and autonomous organizations tend to be more addressable (Rajwani et al. 2015); that is, they are able to speak with one single voice in an efficient way. This may represent and advantage when seeking access to policymakers pressured by time and resources (Braun 2013; van Schendelen 2005), but it also can damage the representativeness of the organization and its capacity to provide input legitimacy to policymakers.

Even though the combination of member involvement and organizational capacity implies clear difficulties and requires overcoming tensions and dilemmas (Jordan and Maloney 2007; Klüver and Saurugger 2013), CSOs that invest in both dimensions are organizationally prepared to effectively relay citizens' demands to policymakers. Importantly, the constituting elements of each organizational dimension presented above are not mutually exclusive. Thus, CSOs can actively involve their members in democratic ways and have the structures that characterize organizational capacity. In other words, some CSOs are expected to be able to accommodate the two organizational dimensions and, thus, approximate the transmission belt ideal.

While this paper focuses on the structures that facilitate information flow from members to the leadership of the organization, it is also important to acknowledge that this relationship might work in the opposite direction. That is, the leadership of the organization may be able to shape members' attitudes and preferences (Berkhout 2013). This is particularly true in the case of transmission belts because they have the necessary capacity to influence their membership base through their own expertise and, at the same time, they have the organizational attributes that facilitate communication with members. In short, the relationship between members and CSOs, particularly among transmission belts, is expected to be bidirectional.

\section{Research Design and Data}

To empirically study the extent to which CSOs organize themselves to function as a transmission belt, the paper relies on data from the INTEREURO project, and more specifically from the INTEREURO Interest Group Survey, a tool designed to examine organizational characteristics and policy activities performed by interest groups to influence policy-making at the EU level. For the first time, this survey generates large- $n$ data on the internal functioning of CSOs active at the EU level. The survey was conducted from March 9 to July 2, 2015 and targeted senior leadership of CSOs (Bernhagen et al. 2016). Initially, 2028 organizations were selected from the Transparency Register of the EU, the OECKL Directory, and via elite interviews and media analyses (Beyers et al. 2016). The object of study of the survey was European and national associations; therefore, firms and individual organizations were excluded from the population. In total, 738 organizations completed the questionnaire, reaching a response rate of 
Table 1 Measuring transmission belts: member involvement and organizational capacity

\begin{tabular}{|c|c|}
\hline Item & Operationalization \\
\hline \multicolumn{2}{|c|}{ Member involvement } \\
\hline Interaction & $\begin{array}{l}0=\text { Organizations do not have a general assembly or an annual general meeting } \\
1=\text { Organizations have a general assembly or an annual general meeting }\end{array}$ \\
\hline Decision making & $\begin{array}{l}0=\text { Members do not participate in the decision-making processes when establishing positions and defining strategies } \\
1=\text { Members participate in the decision-making processes when establishing positions and defining strategies }\end{array}$ \\
\hline Local chapters & $\begin{array}{l}0=\text { Organizations do not have local or regional chapters } \\
1=\text { Organizations have local or regional chapters }\end{array}$ \\
\hline \multicolumn{2}{|c|}{ Organizational capacity } \\
\hline Autonomy & $\begin{array}{l}0=\text { The senior staff of the organization does not have decision-making power on the budget or on hiring staff } \\
1=\text { The senior staff of the organization has decision-making power on the budget and on hiring staff }\end{array}$ \\
\hline Centralization & $\begin{array}{l}0=\text { The apex of the organizations is not influential when establishing positions and defining strategies } \\
1=\text { The apex of the organization is influential when establishing positions and defining strategies }\end{array}$ \\
\hline $\begin{array}{l}\text { Functional } \\
\text { differentiation }\end{array}$ & $\begin{array}{l}0=\text { The organization does not have committees for specific tasks } \\
1=\text { The organization has committees for specific tasks }\end{array}$ \\
\hline
\end{tabular}

$36.2 \%$. To test how the organizational dimensions considered apply to different types of CSOs, the sample includes business as well as citizen CSOs and excludes all the organizations that are not categorized in any of these two groups as well as organizations without members. ${ }^{3}$ This reduces the sample to 500 organizations.

The focus on the CSOs mobilized at the EU level is justified by institutional as well as organizational factors. At the institutional level, CSO's participation is considered as an important way to 'nurture EU's weak democratic legitimacy and contribute to more effective policy-making by bringing the voice of civil society' (Johansson and Lee 2014 , p. 407). EU institutions actively reach out to organizations that link members with decision-makers and as such contribute to the legitimacy and effectiveness of EU governance (European Commission 2001, 2002; KohlerKoch 2010). In this vein, the role of CSOs is particularly relevant at the EU level because they are expected to mediate the representative distance between society and the

\footnotetext{
3 To be precise, business groups correspond to the following survey category "Trade, business \& professional associations," and citizen groups refer to "non-governmental organizations, platforms and networks and similar." The following categories have been excluded from the sample due to the low number of respondents representing these types of groups (in total, they represent 70 organizations): "organizations representing churches and religious communities" ( $n=11)$, "other public or mixed entities, etc." $(n=16)$, "other similar organizations to 'public or mixed entities" " $(n=12)$, "local, regional and municipal authorities (at sub-national level)" ( $n=17)$, and "trade unions" $(n=14)$. Additionally, 128 respondents did not specify the type of group of their organization and, therefore, have been removed from the sample. Lastly, 40 organizations indicated that they did not have members and, thus, have been excluded from the sample.
}

EU (Greenwood 2007). At the organizational level, CSOs active in the EU are complex (multilayered) entities that require certain organizational structure to involve their members and engage with policymakers. The focus on CSOs at the EU level has obvious implications in terms of generalization that are discussed in the concluding section of the paper.

Table 1 presents the operationalization of the six items included to measure the two organizational dimensions. These variables are based on different questions of the INTEREURO Interest Groups Survey. Firstly, the presence or absence of a general assembly or an annual meeting is considered as crucial to enable the involvement of members in the work of the organization (Jordan and Maloney 2007; McFarland 2010), and thus, this binary measure is intended to measure the "Interaction" among members and between members and CSOs' leadership. Secondly, the measurement of 'Decision-making' relies on two sub-items of the questionnaire that are key for CSOs' strategy, namely how they make decisions when (1) establishing their organization's position on policy issues and (2) deciding on advocacy/lobbying strategies and tactics (Binderkrantz 2009). These two items have been grouped based on the results of a principal component analysis (PCA) and confirmed by an acceptable level of a Cronbach's alpha test of reliability $(\alpha=.700)$ (Field 2009, p. 675). This variable has been recoded as 1 when members are involved in the decision-making process and 0 when otherwise, thus, showing the formal decision-making capacity of members to determine the fate of the organization (Johansson and Lee 2014). Thirdly, 'Local chapters' are based on a single question aimed at identifying whether 
the organization has local or regional branches (Fraussen et al. 2015).

Regarding the second dimension on organizational capacity, 'Autonomy' reflects whether the senior staff of the organization has decision-making competences on budgetary issues and hiring staff. By focusing on operational autonomy, which indicates the capacity of the group to take human resource management decisions by itself, this variable is conceived as a powerful indicator of the 'degree of [member] interference in the day-to-day management of the [group]' (Bach 2014, 345). Results have been recoded as 1 when the senior staff can decide on both issues and 0 when otherwise. 'Centralization' is a construct that captures whether the apex of the CSO (i.e., executive director, the chair of the board, and the board of directors) is somewhat or very influential when (1) establishing EU positions and (2) deciding on advocacy and lobbying tactics. Thus, this operationalization reflects the effective concentration of power/influence on the apex of the organization (Albers et al. 2013; Damanpour 1991), or in Pugh et al.'s (1963) terms, the real authority of CSOs' apex. The variable relies on six items that have been grouped after examining the data with a PCA and estimating the reliability of the construct ( $\alpha=.786$ ). Finally, 'Functional differentiation' reflects whether CSOs have committees for specific tasks or not (Klüver 2012, p. 496). 'Appendix 1' presents the complete list of questions used to construct the two dimensions, and Table 4 in 'Appendix 2' includes a correlation matrix among the main variables. ${ }^{4}$

To further explore variation in the organizational forms resulting from the cluster analysis, the paper considers five basic characteristics of CSOs: type of CSO, age, resources, organizational scale, and membership diversity. Type of CSO distinguishes whether the organization is composed of business organizations (i.e., trade, business, and professional associations) or if, instead, gathers citizen organizations (i.e., non-governmental organizations, platforms, and networks and similar). Organization age indicates how old the CSO is. Resources are measured via the equivalent employees working full time in the organizations.

\footnotetext{
4 Table AI in Appendix II presents a correlation matrix of the six variables used to develop the two dimensions. All the correlation coefficients (excluding the ones between the dimensions and the items they are based on) are below .400, ensuring that these are independent variables measuring distinct elements of the organizational structure of CSOs. Additionally, the independence of the variables has been further investigated to ensure that none of the features is a precondition to have a 'second' item. For instance, it could be argued that CSOs need 'Interaction' to actually involve members in 'Decision-making.' However, a close analysis shows that $34.29 \%$ of CSO without 'Interaction' actually involve members in decisionmaking. In this vein, strategic decision making by all the members may be done through non-plenary or face-to-face meetings but via ad hoc or virtual meetings, or even via e-mails or one-to-one consultations between the organization and its members.
}

Organizational scale indicates whether CSOs are national or a supranational association. Lastly, we include membership diversity, which captures how many different types of members has each CSO, the options being: individual members, firms, local and regional governments, national associations, and European associations (see Table 5 in 'Appendix 2' for descriptive statistics and correlations among variables).

\section{Analysis}

The analyses proceed in two steps. Firstly, the paper presents the results of cluster analysis to, subsequently, examines how the resulting clusters relate to basic characteristics of CSOs presented in the previous section.

A cluster analysis is conducted to examine how the constructs of member involvement and organizational capacity are distributed across CSOs. This approach offers a description of organizations by identifying organizational forms of CSOs that resemble each other along the two dimensions identified (Short et al. 2008, p. 1054). Hence, cluster analysis fits the purposes of the paper, namely to assess the extent to which the organizational structure of CSOs conforms to the ideal-type transmission belt and to reveal possible variations. The cluster analysis gathers CSOs into categories such that organizations in the same cluster are more alike to each other than to other clusters (Hair et al. 2008). More specifically, the chosen analysis is Ward's method, a type of hierarchical clustering aimed at joining cases into clusters such that the variance within a cluster is minimized (Szekely and Rizzo 2005). This agglomerative method is appropriate when no outliers are present and when equally sized clusters are expected (Mooi and Sarstedt 2011). ${ }^{5}$ The number of clusters considered is based on the interpretation of the Ward's linkage cluster dendrogram (see Fig. 1 in 'Appendix 2'). To cross-validate this result, the same analysis has been conducted with ten subsamples (Gordon 1998). The resulting clusters of the subsamples have been compared to the ones obtained in the complete sample. In every case, the results of the Chisquare tests comparing the clusters of the whole sample with the ones of the subsamples are significant, confirming the validity of the findings.

\footnotetext{
5 The expectation of equally sized clusters is based on the results of previous works that find substantial variation of categories of CSOs when considering organizational elements (Baroni et al. 2014; Minkoff et al., 2008). Because the two dimensions are equally important to function as a transmission belt, there is no need to weight them, nor to control by which one is more relevant when determining the final clusters. Furthermore, since both dimensions have the same scale, there is no need to standardize the data to prevent a variable with high variability from dominating the cluster analysis.
} 
Table 2 Comparison of cluster characteristics (see footnote 6)

\begin{tabular}{|c|c|c|c|c|c|}
\hline Mean (S.D.) & Passive & Representative & Capable & Balanced & Total \\
\hline Member involvement ${ }^{\dagger}$ & $1(.431)^{*}$ & $2.36(.486)^{*}$ & $1(0)$ & $1.966(.283)^{*}$ & $1.511(.633)$ \\
\hline Interaction $^{\dagger}$ & $.841(370) *$ & $1(0)$ & $.969(.173)$ & $1(0)$ & $.963(.190)$ \\
\hline Decision making ${ }^{\dagger}$ & $.091(.291)^{*}$ & $.692(.468)^{*}$ & $.031(.173)^{*}$ & $.609(.491)^{*}$ & $.325(.469)$ \\
\hline Local chapters ${ }^{\dagger}$ & $.068(.255)^{*}$ & $.667(.477)^{*}$ & $0(0)$ & $.356(.481)^{*}$ & $.224(.418)$ \\
\hline Capacity $^{\dagger}$ & $.750(.438)^{*}$ & $1.282(.456)^{*}$ & $2(0)$ & $2.103(.306)^{*}$ & $1.724(.592)$ \\
\hline Autonomy $^{\dagger}$ & $.023(.151)^{*}$ & $0(0)$ & $.041(.199)$ & $.149(.359)^{*}$ & $.067(.251)$ \\
\hline Centralization $^{\dagger}$ & $.454(.504)^{*}$ & $.718(.456)^{*}$ & $1(0)$ & $.977(.151)^{*}$ & $.862(.346)$ \\
\hline Functional differentiation $^{\dagger}$ & $.272(.451)^{*}$ & $.564(.502)^{*}$ & $.959(.199)^{*}$ & $.977(.151)^{*}$ & $.795(.405)$ \\
\hline Total \% (n) & $16.42(44)$ & $14.55(39)$ & $36.57(98)$ & $32.46(87)$ & $100(268)$ \\
\hline
\end{tabular}

$P$ values $\left(^{\dagger}\right)$ indicate significance for a test of equality of a variable's distribution among the four clusters; analysis of variance for continuous variables and Pearson Chi-square for categorical variables

$P$ values (*) indicate significance for a test of equality of a variable's distribution within a cluster versus the variable's overall distribution; $t$ statistics for continuous variables and Pearson Chi-square for categorical variables

$*,{ }^{\dagger} p<.05$

Table 2 presents the main results of the cluster analysis (see also Fig. 2 in 'Appendix 2'). The cluster analysis generates four different combinations of the two dimensions. That is, based on the presence of the organizational features associated with involving members and having organizational capacity, the analysis discerns four different ways in which CSOs organize. ${ }^{6}$ This finding is aligned with previous studies that highlighted organizational diversity among CSOs, even within citizen or business CSOs (Baroni et al. 2014; Minkoff et al. 2008). More specifically, the results show a similar pattern to what Minkoff et al. (2008) found in the US context: There is substantial variation in the organizational structures of CSOs active at the EU level. This variation is very relevant considering the institutional pressure (DiMaggio and Powell 1983) at the EU level for organizations that function as transmission belts (European Commission 2001, 2002), or that are professionalized (Klüver and Saurugger 2013; Maloney 2015). Despite these isomorphic forces, CSOs seem to have some degree of discretion to develop the organizational structure that they believe is more appropriate for their own purposes, and not the one that is mostly demanded from public institutions.

Out of the 268 observations ${ }^{7}$ included in the analysis, 44 CSOs $(16.42 \%)$ have an organizational structure that score

\footnotetext{
${ }^{6}$ To further validate the results, a discriminant analysis of the identified clusters and the two dimensions included in the clustering process has been conducted. Results indicate that $96.64 \%$ of the CSOs were correctly classified by the discriminant analysis. If the cases are classified manually in a two-by-two matrix where ranking 0 and 1 is considered as low and 2 and 3 is regarded as high, then we see that $93.1 \%$ of the cases fall into the same categories.

7 Missing data are mainly explained by non-responses to the questions used to construct the variable "Centralization." This variable has $38 \%$ of missing responses $(\mathrm{n}=223)$. A $t$ test analysis for each variable has been conducted to assess non-response bias of
}

low in both member involvement and organizational capacity. Consequently, organizations in this cluster are labeled as Passive. More specifically, CSOs in this cluster have a poorly developed organizational structure and can be considered as loose and weakly connected networks that invest few resources to engage with their own members or have organizational capacity.

The second cluster (i.e., named as Representative) gathers 39 CSOs $(14.55 \%)$ that possess organizational features that foster member involvement, yet do not have the characteristics that are considered indicative of the capacity to generate, process, and transfer members' preferences and information to policymakers. Hence, Representative organizations are mainly oriented toward their membership base, promoting participation and fostering the internal cohesion. These organizations are more akin to what Schmitter and Streeck termed clubs or forums, with organizational structures that facilitate interaction among members, participation in collective activities, exchange of information and expertise, and formation of a collective identity (Schmitter and Streeck 1999). The existence of such a cluster demonstrates that despite the current debate about the democratic flaws of organized interests (Halpin 2010; Jordan and Maloney 2007), there are still some organizations that have the necessary organizational features to be internally democratic. Yet, the low percentage of Representative CSOs is surprising considering the EU's explicit request for representative CSOs that are connected with their members (Kohler-Koch 2010).

The third cluster gathers 98 CSOs $(36.57 \%)$ with those organizational features that are expected to foster their

Footnote 7 continued

the main variables. Results are not significant for any of the two organizational dimensions. 
capacity to effectively generate, process, and transfer information to policymakers. However, as the structure to engage with members and supporters of most of the organizations in this cluster is underdeveloped, they have been labeled as Capable organizations. This finding is aligned with Halpin's (2006) observation that not all CSOs seek representation. Additionally, it speaks to the trend toward professionalization that has been identified at the EU level (Jordan and Maloney 2007; Klüver and Saurugger 2013; Maloney 2015). As noted by Van Deth and Maloney (2012), there is a gradual change in which organizations become more specialized and centralized and give less priority to organizational democracy. In this regard, organizations in this cluster are expected to be more strongly focused on policy advocacy and on the provision of expertise to policymakers. A paradigmatic example of an organization clustered as 'Capable' is Friends of the Earth Europe, an organization that, as Rootes (2009, pp. 210-211) noted, was not 'established to be responsive or accountable to members. Instead, they were founded to be 'uninhibited campaigning' groups and campaign effectiveness was privileged over democratic involvement.' Intriguingly, results indicate that there are twice as many Capable groups as Representative ones. As noted, this is surprising if we consider the rhetoric of the Commission and its preference for representative groups that favor democratic participation (European Commission 2001, 2002); yet, the dominance of Capable over Representative groups is aligned with recent research assessing the representational capacity and the policy engagement of interest groups at the EU level (Berkhout et al. 2017).

Finally, 87 organizations $(32.46 \%)$ closely approximate the transmission belt ideal, with a high potential to link members' preferences to policymakers (Berkhout et al. 2017; Braun 2015). More specifically, these CSOs are able to effectively represent their members thanks to democratic structures, and transform the preferences of their members and other organizational resources into relevant access goods for policymakers. Because of their ability to integrate both dimensions, organizations in this cluster have been labeled as Balanced. CSOs in this cluster meet the demands of the Commission for representative organizations that effectively functions as intermediaries of the public, enhancing input and output legitimacy of EU institutions (European Commission 2001; Greenwood 2007; Kohler-Koch and Quittkat 2013). Additionally, the existence of this cluster demonstrates that the tensions and dilemmas associated with having both organizational dimensions are not insurmountable. That is, even though involving members and having organizational capacity are not easy or cheap (Jordan and Maloney 2007), an important number of CSOs successfully combine both organizational dimensions. $^{8}$

To further explore these results, this second part of the section examines the relationship between the four clusters and five basic variables of CSOs: type of organization (i.e., citizens vs. businesses), organizational age, resources, organizational scale, and membership diversity. Results in Table 3 do not present a clear linkage between CSO characteristics and the four clusters. That is, none of the five characteristics is related to the four organizational forms resulting from the cluster analysis. Yet, there are significant relationships in Table 3 that are worth discussing. Firstly, being Representative, Capable or Balanced is not significantly related to whether the CSO gathers citizen or business organizations. With the only exception of Passive organizations which are significantly associated with citizen groups, the results demonstrate that the distinction between business and citizen groups, and the assumptions linked to each of them, does not hold when considering the organizational form of CSOs (cf., Hollman 2017). More specifically, our findings suggest that business and citizen groups are equally capable of functioning as transmission belts (cf., Flöthe and Rasmussen 2018), which contradicts previous investigations that find significant relationship between being a business group and acting as transmission belt (Berkhout et al. 2017). More generally, this result reinforces the applicability of this conceptualization across any type of CSOs, regardless of whether they are business or citizen organizations. Secondly, the cluster labeled as Passive gathers the youngest organizations. From an organizational perspective, Passive CSOs may be evolving toward one of the three typologies that are regarded as legitimate in the EU environment (Hannan and Freeman 1977). However, an alternative explanation could be that these younger organizations use new, less-formalized, or untraditional mechanisms to communicate with their members and policymakers (cf., Fraussen and Halpin 2018). Regarding the amount of resources, it is only significantly and positively related to Representative organizations; that is, CSOs that actively involve their members

\footnotetext{
${ }^{8}$ The internal validity of the results of the cluster analysis is analyzed by testing the differences between the clusters and the variables used to obtain the clusters. The test of equality of the variable's distribution among the four clusters shows that the two dimensions, as well as the six variables used to construct them, vary significantly across the four resulting clusters. Moreover, the test of equality of a variable's distribution within a cluster versus the variable's overall distribution indicates that all the variables within clusters differ significantly from the same variables in the other clusters. The only nonsignificant results are those variables with integer values and no standard variation. Furthermore, the variables "Interaction" for Representative and Capable organizations and "Autonomy" for Representative organizations also have nonsignificant distributions when compared with the overall distribution.
} 
Table 3 Logistic regressions by cluster

\begin{tabular}{|c|c|c|c|c|}
\hline & Passive & Representative & Capable & Balanced \\
\hline CSO type: citizens & REF & REF & REF & REF \\
\hline CSO type: businesses & $.514 *(.190)$ & $1.017(.404)$ & $1.548(.438)$ & $.953(.274)$ \\
\hline Organizational age & $.983 *(.010)$ & $1.001(.008)$ & $1.004(.006)$ & $1.003(.006)$ \\
\hline Resources (FTE) & $.998(.005)$ & $1.012 * *(.005)$ & $.995(.004)$ & $.991(.007)$ \\
\hline Organizational scale: National CSOs & REF & REF & REF & REF \\
\hline Organizational scale: Supranational CSOs & $.528(.247)$ & $1.527(.899)$ & $.858(.328)$ & $1.394(.586)$ \\
\hline Membership diversity & $.908(.134)$ & $.999(.154)$ & $1.274 * *(.141)$ & $.796 *(.098)$ \\
\hline $\mathrm{N}$ & 248 & 248 & 248 & 248 \\
\hline Constant & $.877(.550)$ & $.088 * * *(.068)$ & $.295 * *(.151)$ & $.587(.324)$ \\
\hline Log likelihood & -103.085 & -95.256 & -159.849 & -152.443 \\
\hline Pseudo $R$ square & .05 & .06 & .03 & .03 \\
\hline
\end{tabular}

Odds ratio, standard error in parenthesis

$* p<.1 ; * * p<.05 ; * * * p<.01$

require more resources in terms of staff. Intriguingly, the distinction between national and supranational CSOs does not matter for explaining their organizational form. Finally, membership diversity (i.e., whether the organizations gather more or less heterogeneous members) is significantly related to Capable and Balanced organizations, but in opposite ways. Whereas more heterogeneous CSOs tend to organize themselves as Capable organizations that hardly involve their members, homogenous CSOs tend to be organized as Balanced organizations. CSOs with higher levels of membership diversity have lower chances of investing in democratic structures, but do invest in organizational capacity. That is, CSOs with a heterogeneous membership base emphasize a top-down perspective to control their members (van der Pijl and Sminia 2004; Williamson 1981). In contrast, the more homogenous the CSO, the higher the likelihood that it can be organized as a transmission belt (Berkhout 2013; Kröger 2018). That is, having the same type of members facilitates the development of organizational structures aimed at involving members and at having the necessary organizational structures to generate, process, and transfer information to policymakers.

\section{Conclusion}

The capacity of CSOs to act as transmission belts is crucial to their contribution to policy processes and democracy. This paper theoretically develops and empirically assesses the organizational ability of CSOs to function as transmission belts that connect members' preferences with policymakers. As clarified in the Introduction, the literature either considers only one side of the transmission belt coin (by focusing on engagement with members or on having organizational capacity) or refers to organizational form in very general terms (e.g., by using organizational type as proxy for certain organizational feature and practices). To move the literature forward and increase our understanding of the role of CSOs in policy-making, this paper theoretically unpacks the transmission belt notion based on the distinction of two organizational dimensions: member involvement and organizational capacity. The paper offers a fine-grained conceptualization of the constituting elements of these organizational dimensions and unites them in a new theoretical framework of organizational form to assess the capacity of CSOs to function as transmission belts. This tool can be understood as a foundation to go beyond traditional proxies and to better theorize on the role of CSOs in representative democracies. In this vein, the empirical examination of this conceptualization indicates that $32 \%$ of EU CSOs approximate the ideal-type transmission belt, as they have a balanced organizational structure with elements aimed at both involving members and having organizational capacity. This suggests that at least some CSOs indeed are able to manage the tensions related to the challenge of both listening to members and talking to policymakers. Yet, we also observe important variation concerning the organizational form, as the majority of the CSOs do not have the organizational features associated with both processes. While almost $50 \%$ of the organizations prioritize either member involvement or organizational capacity, $16 \%$ invest very little in both organizational dimensions. Hence, despite the rhetoric of the Commission and its preference for CSOs that function as transmission belts, there is significant variation in how CSOs are organized, which results in unequal capacities to function as a transmission belt.

It is worth to acknowledge a potential source of bias related to the research design and the EU-centered sample. 
A particularity of CSOs operating at the EU level is that they are encouraged by EU institutions to function as a transmission belt, which, from an institutionalist perspective, may lead to higher incidence of this type of organizations (cf., DiMaggio and Powell 1983). Yet, they also face a larger distance between elementary membership units and the decision-making center, which places higher organizational demands to connect members to policymakers. Therefore, the distribution of the different typologies of CSOs identified may vary across institutional settings that place different institutional and organizational pressures on CSOs organizational structure (cf., Berkhout et al. 2017). Consequently, future comparative research could examine the relationship between systems of interest intermediation and the presence of CSOs operating as transmission belts. Besides, this paper has analyzed how CSOs are organized by using reported survey data that tap into key organizational elements of each dimension. Future research might build upon this conceptualization by conducting in-depth qualitative investigations to further examine the validity of the measurement and operationalization of the variables that compose each organizational dimension and to gain more insight on how transmission belts are organized. Lastly, this paper builds upon a functionalist approach to conceptualize CSOs organizational structure. Yet, as has been already noted, the data available do not allow us to know whether CSOs are deliberatively organized as they are or if instead, and despite their willingness to be organized in a certain way, they fail to set up the necessary organizational features to achieve their goals. In addition, some CSOs may have concrete organizational structures not because they serve a concrete function, but because they are the most accepted and legitimate in the EU institutional environment (DiMaggio and Powell 1983). This could explain the limited explanatory power of the main features included in the analysis of Table 3 and the higher frequency of Balanced and Capable CSOs at the EU level-which are the forms that are more frequently demanded by EU institutions (European Commission 2001, 2002; Klüver and Saurugger 2013; Maloney 2015). In that regard, future research could combine functionalist and institutionalist approaches to assess the extent to which the organizational form of CSOs rationally serves certain functions and responds to institutional and isomorphic forces (cf., Pierson 2000).

Returning to the role of CSOs in policy-making and democracy, the results obtained suggest that approximately one-third of CSOs operating at the EU level can contribute to the legitimacy and effectiveness of EU governance by connecting members and supporters with decision-makers (European Commission 2001, 2002). In contrast to Balanced organizations, the contribution of Representative and Capable organizations to EU governance can be questioned, or at least seems of a different nature. On the one hand, Representative organizations are relevant to foster input legitimacy and compliance with common goals because of their engagement and strong connection with members. On the other hand, Capable organizations can contribute to EU effectiveness due to their organizational capacity to be politically active. More specifically, Capable organizations can mostly contribute to EU governance with output legitimacy as well as expertise. Consequently, only a minority of CSOs are organizationally prepared to account as surrogates for the democratic deficit of the EU by fostering democratic participation and, in particular, the effectiveness and legitimacy of the policy process. That is, only Balanced organizations are organizationally prepared to contribute to different types of legitimacies and resources that are highly valued by EU institutions. In that regard, future research may also look into whether CSOs that effectively involve members and have organizational capacity are, in fact, more relevant among policymakers and thus contribute to more legitimate and effective governance systems.

Acknowledgements I am grateful to Caelesta Braun and Bert Fraussen for their guidance, support and constructive suggestions throughout the research process. I would also like to thank all the scholars involved in the INTEREURO Interest Group Survey for granting me access to the survey data. The paper benefited from excellent comments from Darren Halpin, Michelle Hollman and the participants of the Politicologenetmaal Conference (Leiden, 1-2 June 2017). I am thankful to the journal reviewers for their helpful feedback and constructive criticism. Lastly, this research received financial support from the Netherlands Organisation for Scientific Research (Nederlandse Organisatie voor Wetenschappelijk Onderzoek (NWO)), grant 452-14-012 (Vidi scheme).

Open Access This article is distributed under the terms of the Creative Commons Attribution 4.0 International License (http://crea tivecommons.org/licenses/by/4.0/), which permits unrestricted use, distribution, and reproduction in any medium, provided you give appropriate credit to the original author(s) and the source, provide a link to the Creative Commons license, and indicate if changes were made.

\section{Appendix 1: Selected Questions of the INTEREURO Interest Group Survey}

\section{Member Involvement}

\section{Interaction}

Does your organization have any of the following? Please tick all boxes that apply.

\section{A general assembly or an annual general meeting}

\section{Decision making:}


Organizations like yours can make decisions in different ways, such as consensus among individual members or board members or by voting procedures. Can you please indicate below how your organization primarily makes decisions in the following areas?

\section{Organizational Capacity}

1. Autonomy

Organizations like yours can make decisions in different

\begin{tabular}{|c|c|c|c|c|c|c|}
\hline & $\begin{array}{l}\text { Consensus } \\
\text { among } \\
\text { members }\end{array}$ & $\begin{array}{l}\text { Voting } \\
\text { among the } \\
\text { members }\end{array}$ & $\begin{array}{l}\text { Consensus } \\
\text { in board }\end{array}$ & $\begin{array}{l}\text { Voting } \\
\text { in the } \\
\text { board }\end{array}$ & $\begin{array}{c}\text { Senior } \\
\text { staff take } \\
\text { these } \\
\text { decisions }\end{array}$ & Other \\
\hline $\begin{array}{l}\text { Establishing your } \\
\text { organization's } \\
\text { position on policy } \\
\text { issues }\end{array}$ & C & $\sigma$ & $r$ & $r$ & $r$ & $r$ \\
\hline $\begin{array}{l}\text { Deciding on } \\
\text { advocacy/lobbying } \\
\text { strategies and tactics }\end{array}$ & $r$ & $C$ & $r$ & $r$ & $C$ & 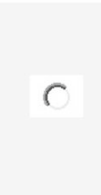 \\
\hline
\end{tabular}

3. Local chapters:

Does your organization have any of the following? Please tick all boxes that apply.

\section{Local or regional chapters}

ways, such as consensus among individual members or board members or by voting procedures. Can you please indicate below how your organization primarily makes decisions in the following areas? 


\begin{tabular}{|c|c|c|c|c|c|c|}
\hline & $\begin{array}{c}\text { Consensus } \\
\text { among } \\
\text { members }\end{array}$ & $\begin{array}{l}\text { Voting } \\
\text { among the } \\
\text { members }\end{array}$ & $\begin{array}{l}\text { Consensus } \\
\text { in board }\end{array}$ & $\begin{array}{l}\text { Voting } \\
\text { in the } \\
\text { board }\end{array}$ & $\begin{array}{c}\text { Senior } \\
\text { staff take } \\
\text { these } \\
\text { decisions }\end{array}$ & Other \\
\hline Budget & $r$ & $r$ & $c$ & $C$ & $r$ & $r$ \\
\hline Hiring staff & c & $r$ & $r$ & $C$ & $C$ & r \\
\hline
\end{tabular}

\section{Centralization}

Thinking about your organization's position on EU policies, how would you rate the relative influence of the following actors?

\begin{tabular}{|lcccc|}
\hline & $\begin{array}{c}\text { Somewhat } \\
\text { influential }\end{array}$ & $\begin{array}{c}\text { Not very } \\
\text { influential }\end{array}$ & $\begin{array}{c}\text { Not at all } \\
\text { influential }\end{array}$ \\
\hline $\begin{array}{l}\text { Executive director } \\
\text { Chair of the board }\end{array}$ & 0 & 0 & 0 & 0 \\
The board of & & 0 & 0 & 0 \\
directors/executive & 0 & & & \\
committee & & & & \\
\hline
\end{tabular}

Thinking about your organization's decisions on advocacy and lobbying tactics, how would you rate the relative influence of the following actors?

\begin{tabular}{|lcccc|}
\hline & $\begin{array}{c}\text { Somewhat } \\
\text { influential }\end{array}$ & $\begin{array}{c}\text { Not very } \\
\text { influential }\end{array}$ & $\begin{array}{c}\text { Not at all } \\
\text { influential }\end{array}$ \\
\hline $\begin{array}{l}\text { Executive director } \\
\text { Chair of the board }\end{array}$ & 0 & 0 & 0 & 0 \\
The board of & & 0 & 0 & 0 \\
directors/executive & 0 & & & \\
committee & & & & \\
\hline
\end{tabular}

3. Functional differentiation: 
Does your organization have any of the following?

Please tick all boxes that apply.

Committees for specific tasks

\section{Appendix 2}

See Figs. 1, 2 and Tables 4, 5.

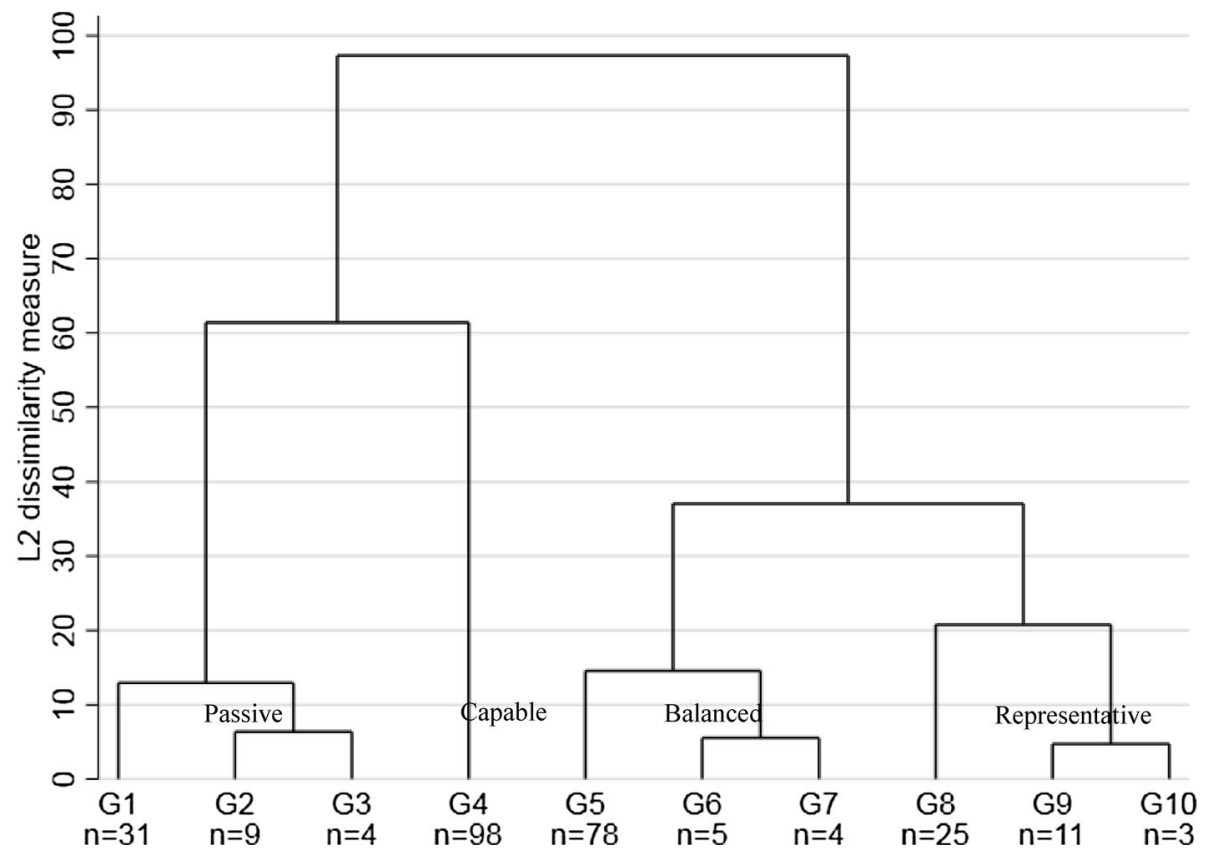

Fig. 1 Dendrogram for Ward's linkage cluster analysis

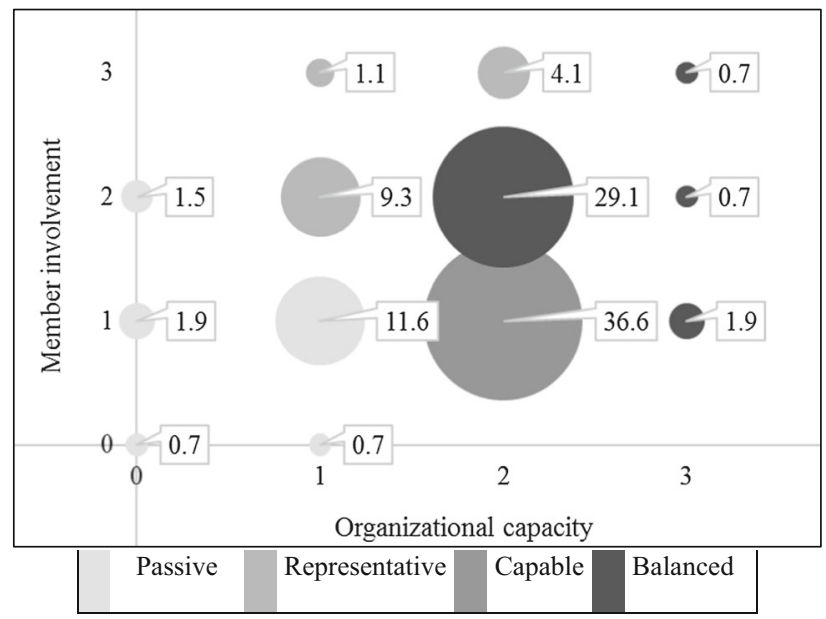

Fig. 2 Scatter plot of CSOs by cluster (weighted by \%) 
Table 4 Correlation matrix of organizational variables

\begin{tabular}{|c|c|c|c|c|c|c|c|}
\hline & 1 & 2 & 3 & 4 & 5 & 6 & 7 \\
\hline 1. Member involvement & 1 & & & & & & \\
\hline 2. Interaction & $.4094 *$ & 1 & & & & & \\
\hline 3. Decision making & $.6863^{*}$ & .0042 & 1 & & & & \\
\hline 4. Local chapters & $.5606^{*}$ & .0344 & -.0603 & 1 & & & \\
\hline 5. Organizational capacity & .1082 & $.2145^{*}$ & .0542 & -.0182 & 1 & & \\
\hline 6. Autonomy & -.052 & $-.1702 *$ & -.076 & .0711 & $.3217^{*}$ & 1 & \\
\hline 7. Centralization & .061 & $.1881^{*}$ & .0626 & -.0909 & $.6633^{*}$ & -.0196 & 1 \\
\hline 8. Functional differentiation & $.1354 *$ & $.3044 *$ & -.0019 & $.0987 *$ & $.7047 *$ & -.0889 & $.1508 *$ \\
\hline
\end{tabular}

$* \mathrm{p}<.05$

Table 5 Descriptive statistics and correlation matrix of the four clusters and explanatory factors

\begin{tabular}{|c|c|c|c|c|c|c|c|c|c|c|}
\hline Variables & Mean (SD) & Min-max & 1 & 2 & 3 & 4 & 5 & 6 & 7 & 8 \\
\hline 1. Passive & $.164(.371)$ & $0-1$ & 1 & & & & & & & \\
\hline 2. Responsive & $.145(.353)$ & $0-1$ & $-.182 *$ & 1 & & & & & & \\
\hline 3. Capable & $.365(.482)$ & $0-1$ & $-.336^{*}$ & $-.313^{*}$ & 1 & & & & & \\
\hline 4. Balanced & $.324(.469)$ & $0-1$ & $-.307 *$ & $-.286^{*}$ & $-.526^{*}$ & 1 & & & & \\
\hline 5. CSO type & $.559(.497)$ & $0-1$ & -.114 & .004 & .065 & .021 & 1 & & & \\
\hline 6. Organizational age & $30.667(25.409)$ & $3-168$ & $-.135^{*}$ & .031 & .063 & .021 & $.174 *$ & 1 & & \\
\hline 7. Resources (FTE) & $16.862(70.543)$ & $0-1000$ & -.029 & $.218^{*}$ & -.059 & -.083 & .015 & $.188^{*}$ & 1 & \\
\hline 8. Organizational scope & $.843(.364)$ & $0-1$ & -.031 & -.055 & -.014 & .080 & -.093 & $-.205^{*}$ & $-.224 *$ & 1 \\
\hline 9. Membership diversity & $2.123(1.258)$ & $0-6$ & -.011 & .052 & .074 & -.106 & $-.212 *$ & $-.134 *$ & .093 & .075 \\
\hline
\end{tabular}

$* p<.05$

\section{References}

Ainsworth, S., \& Sened, I. (1993). The role of lobbyists: Entrepreneurs with two audiences. American Journal of Political Science, 37(3), 834-866.

Albareda, A., \& Braun, B. (forthcoming) Organizing transmission belts: The effect of organizational design on interest group access to EU policymaking. Journal of Common Market Studies. https://doi.org/10.1111/jcms.12831.

Albers, S., Wohlgezogen, F., \& Zajac, E. J. (2013). Strategic alliance structures: An organization design perspective. Journal of Management, 42(3), 582-614.

Bach, T. (2014). The autonomy of government agencies in Germany and Norway: Explaining variation in management autonomy across countries and agencies. International Review of Administrative Sciences, 80(2), 341-361.

Baroni, L., Carroll, B. J., William Chalmers, A., Marquez, L. M. M., \& Rasmussen, A. (2014). Defining and classifying interest groups. Interest Groups \& Advocacy, 3(2), 141-159.

Berkhout, J. (2013). Why interest organizations do what they do: Assessing the explanatory potential of 'exchange' approaches. Interest Groups \& Advocacy, 2(2), 227-250.

Berkhout, J., Hanegraaff, M., \& Braun, C. (2017). Is the EU different? Comparing the diversity of national and EU-level systems of interest organisations. West European Politics, 40(5), $1109-1131$.
Bernhagen, P., Beyers, J., Braun, C., Fink-Hafner, D., Heylen, F., Maloney, W., et al. (2016). INTEREURO Survey: Activities and Strategies of European Interest Groups: A Snapshot from the INTEREURO Survey. Stuttgart.

Berry, J. M. (1984). The Interest Group Society. Boston: Little, Brown and Company.

Berry, J. M., Portney, K. E., \& Thomson, K. (1993). The rebirth of urban democracy. Washington DC: Brookings Institution Press.

Beyers, J., Bernhagen, P., Braun, C., Fink-Hafner, D., Heylen, F., Maloney, W. A., et al. (2016). INTEREURO Interest Group Survey. Data Set.

Beyers, J., \& Braun, C. (2014). Ties that count: explaining interest group access to policymakers. Journal of Public Policy, 34(1), 93-121.

Binderkrantz, A. S. (2009). Membership recruitment and internal democracy in interest groups: Do group-membership relations vary between group types? West European Politics, 32(3), $657-678$.

Braun, C. (2013). The driving forces of stability: Exploring the nature of long-term bureaucracy-interest group interactions. Administration \& Society, 45(7), 809-836.

Braun, C. (2015). Lobbying as a Leveraged Act: On resource dependencies and lobby presence. In D. Lowery, D. R. Halpin, \& V. Gray (Eds.), The organizational ecology of interest communities: Assessment and Agenda (pp. 137-156). Basingstoke: Palgrave Macmillan. 
Caimo, A., \& Lomi, A. (2015). Knowledge sharing in organizations: A Bayesian analysis of the role of reciprocity and formal structure. Journal of Management, 41(2), 665-691.

Chandler, A. D. (1962). Strategy and structure: Chapters in the history of the industrial enterprise. Cambridge: M.I.T. Press.

Christensen, T., Lægreid, P., \& Rykkja, L. H. (2016). Organizing for crisis management: Building governance capacity and legitimacy. Public Administration Review, 76(6), 887-897.

Damanpour, F. (1991). Organizational innovation: A meta-analysis of effects of determinants and moderators. Academy of Management Journal, 34(3), 555-590.

Daugbjerg, C., Fraussen, B., \& Halpin, D. R. (2018). Interest groups and policy capacity: Modes of engagement, policy goods and networks. In X. Wu, M. Howlett, \& M. Ramesh (Eds.), Policy capacity and governance (pp. 243-261). Cham: Palgrave Macmillan.

DiMaggio, P. J., \& Powell, W. W. (1983). The iron cage revisited: Institutional isomorphism and collective rationality in organizational fields. American Sociological Review, 48(2), 147-160.

Easton, D. (1971). The political system: An inquiry into the State of Political Science. New York: Knopf.

Eisinger, P. (2002). Organizational capacity and organizational effectiveness among street-level food assistance programs. Nonprofit and Voluntary Sector Quarterly, 31(1), 115-130.

European Commission. (2001). European governance: A white paper. Brussels: European Commission.

European Commission. (2002). Communication from the Commission: Towards a Reinforced Culture of Consultation and Dialogue-General Principles and Minimum Standards for Consultation of Interested Parties by the Commission. Brussels.

Field, A. (2009). Discovering statistics using SPSS (3rd ed.). London: Sage Publications.

Fioretti, G., \& Bauke, V. (2004). A cognitive approach to organizational complexity. Tinbergen Institute Discussion Paper, 04-033(1), 1-32.

Flöthe, L., \& Rasmussen, A. (2018). Public voices in the heavenly chorus? Group type bias and opinion representation. Journal of European Public Policy, 1-19. https://doi.org/10.1080/ 13501763.2018.1489418.

Fraussen, B., \& Beyers, J. (2016). Who's in and who's out?: Explaining access to policymakers in Belgium. Acta Politica, 51(2), 214-236.

Fraussen, B., Beyers, J., \& Donas, T. (2015). The expanding core and varying degrees of insiderness: Institutionalised Interest Group Access to Advisory Councils. Political Studies, 63(3), 569-588.

Fraussen, B., \& Halpin, D. R. (2017). Think tanks and strategic policy-making: the contribution of think tanks to policy advisory systems. Policy Sciences, 50(1), 105-124.

Fraussen, B., \& Halpin, D. R. (2018). How do interest groups legitimate their policy advocacy? Reconsidering linkage and internal democracy in times of digital disruption. Public Administration, 96(1), 23-35.

Fredericksen, P., \& London, R. (2000). Disconnect in the Hollow State: The Pivotal Role of Organizational Capacity in Community-Based Development Organizations. Public Administration Review, 60(3), 230-239.

Gordon, A. D. (1998). Cluster Validation. In C. Hayashi, K. Yajima, H. H. Bock, N. Ohsumi, Y. Tanaka, \& Y. Baba (Eds.), Data science, classification, and related methods. Tokyo: Springer.

Greenwood, J. (2007). Organized Civil Society and Democratic Legitimacy in the European Union. British Journal of Political Science, 37(02), 333.

Greenwood, R., \& Miller, D. (2010). Tackling design anew: Getting back to the heart of organizational theory executive overview. Academy of Management Perspectives, 24, 78-88.
Hair, J., Black, W., Babin, B., Anderson, R., \& Tatham, R. (2008). Multivariate data analysis (7th ed.). Upper Saddle River, NJ, NJ: Pearson Prentice Hall.

Halpin, D. R. (2006). The participatory and democratic potential and practice of interest groups: Between solidarity and representation. Public Administration, 84(4), 919-940.

Halpin, D. R. (2010). Groups, democracy and representation: between promise and practice. Manchester: Mancester University Press.

Halpin, D. R. (2014). The Organization of Political Interest Groups: Designing advocacy. New York: Routledge.

Halpin, D. R., \& Fraussen, B. (2017). Laying the Groundwork: Linking Internal Agenda-Setting Processes Of Interest Groups to Their Role in Policy Making. Administration \& Society. https:// doi.org/10.1177/0095399717728094.

Halpin, D. R., Fraussen, B., \& Nownes, A. J. (2018). The balancing act of establishing a policy agenda: Conceptualizing and measuring drivers of issue prioritization within interest groups. Governance, 31(2), 215-237.

Hannan, M. T., \& Freeman, J. (1977). The population ecology of organizations. American Journal of Sociology, 82(5), 929-964.

Hayes, M. (1986). The new group universe. In C. Press (Ed.), Interest Group Politics (pp. 133-145). Washington, DC: CQ Press.

Heaney, M. T. (2004). Outside the issue niche: The multidimensionality of interest group identity. American Politics Research, 32(6), 611-651.

Hollman, M. (2017). The Private Life Of Groups-How Internal Organisational Structures Shape Interest Group Agency In The European Union. University of Bremen.

Johansson, H., \& Lee, J. (2014). Bridging the gap: How do EU-based civil society organisations acquire their internal representation? VOLUNTAS: International Journal of Voluntary and Nonprofit Organizations, 25(2), 405-424.

Jordan, G., \& Maloney, W. A. (1998). Manipulating membership: Supply-side influences on group size. British Journal of Political Science, 28(2), 389-409.

Jordan, G., \& Maloney, W. A. (2007). Democracy and Interest Groups: Enhancing Participation?. London: Palgrave Macmillan.

King, B. G., Felin, T., \& Whetten, D. A. (2010). Finding the organization in organizational theory: A meta-theory of the organization as a social actor. Organization Science, 21(1), 290-305.

Klüver, H. (2012). Informational lobbying in the European Union: The effect of organisational characteristics. West European Politics, 35(3), 491-510.

Klüver, H., \& Saurugger, S. (2013). Opening the black box: The professionalization of interest groups in the European Union. Interest Groups \& Advocacy, 2(2), 185-205.

Kohler-Koch, B. (2010). Civil society and EU democracy: 'astroturf' representation? Journal of European Public Policy, 17(1), $100-116$.

Kohler-Koch, B. (2012). Post-Maastricht civil society and participatory democracy. Journal of European Integration, 34(7), 809-824.

Kohler-Koch, B., \& Quittkat, C. (2013). De-mystification of participatory democracy. Oxford: Oxford University Press.

Kröger, S. (2018). How limited representativeness weakens throughput legitimacy in the EU: The example of interest groups. Public Administration, 1-14. https://doi.org/10.1111/padm.12410.

Maier, F., \& Meyer, M. (2011). Managerialism and beyond: Discourses of Civil Society Organization and Their Governance Implications. VOLUNTAS: International Journal of Voluntary and Nonprofit Organizations, 22(4), 731-756.

Maloney, W. A. (2015). Organizational populations: professionalization, maintenance and democracy delivery. In D. Lowery, D. 
R. Halpin, \& V. Gray (Eds.), The organizational ecology of interest communities: Assessment and Agenda (pp. 99-116). London: Palgrave Macmillan.

Maloney, W. A., \& Saurugger, S. (2014). The Professionalization of Interest Group Politics in the EU: Patronage and the Logics of Influence and Members.

McFarland, A. (2010). Interest Group Theory. In L. S. Maisel, J. M. Berry, \& G. C. Edwards (Eds.), The Oxford handbook of American political parties and interest groups (pp. 37-56). Oxford: Oxford University Press.

Miller, D. (1996). Configurations revisited. Strategic Management Journal, 17, 505-512.

Minkoff, D., Aisenbrey, S., \& Agnone, J. (2008). Organizational diversity in the U.S. advocacy sector. Social Problems, 55(4), $525-548$.

Mintzberg, H. (1979). The structuring of organizations: A synthesis of the research. Englewood Cliffs, NJ: Prentice-Hall.

Misener, K., \& Doherty, A. (2009). A case study of organizational capacity in nonprofit community sport. Journal of Sport Management, 23, 457-482.

Moe, T. M. (1991). Politics and the Theory of Organization. Journal of Law Economics and Organization, 7, 106-129.

Mooi, E., \& Sarstedt, M. (2011). A concise guide to market research: The process, data, and methods using SPSS statistics. Berlin: Springer.

Muñoz Marquez, L. M. (2016). The Relevance of Organizational Structure to NGOs' Approaches to the Policy Process. VOLUNTAS: International Journal of Voluntary and Nonprofit Organizations, 27(1), 465-486.

Naoi, M., \& Krauss, E. (2009). Who lobbies whom? under alternative special interest politics electoral systems San Diego. American Political Science Political Science, 53(4), 874-892.

Pierson, P. (2000). The limits of design: Explain institutional origins and change. Governance, 13(4), 475-499.

Poguntke, T. (2002). Party organizational linkage: Parties without firm social roots? In K. R. Luther \& F. Müller-Rommel (Eds.), Political Parties in the New Europe (pp. 43-62). Oxford: Oxford University Press.

Pollitt, C., Talbot, C., Caulfield, J., \& Smullen, A. (2004). Agencies. Basingstoke: Palgrave Macmillan.

Pugh, D. S., Hickson, D. J., Hinings, C. R., Macdonald, K. M., Turner, C., \& Lupton, T. (1963). A conceptual scheme for organizational analysis. Administrative Science Quarterly, 8(3), 289-315.

Pugh, D. S., Hickson, D. J., Hinings, C. R., \& Turner, C. (1968). Dimensions of organization structure. Administrative Science Quarterly, 13, 65-105.
Putnam, R. (1993). What makes democracy work? National Civic Review, 82(2), 101-107.

Rajwani, T., Lawton, T. C., \& Phillips, N. (2015). The "voice of industry": Why management researchers should pay more attention to trade associations. Strategic Organization, 13, 224-232.

Rasmussen, A., Carroll, B. J., \& Lowery, D. (2014). Representatives of the public? Public opinion and interest group activity. European Journal of Political Research, 53(2), 250-268.

Rootes, C. (2009). Environmentalism. Environmental NGOs and the environmental movement in England. In N. Crowson, M. Hilton, \& J. McKay (Eds.), NGOs in contemporary Britain: Non-state actors in society and politics since 1945 (pp. 201-221). Basingstoke: Palgrave Macmillan.

Schmitter, P. C., \& Streeck, W. (1999). The Organization of Business Interests. Studying the Associative Action of Business in Advanced Industrial Societies, 1-95.

Short, J. C., Payne, G. T., \& Ketchen, D. J. (2008). Research on organizational configurations: Past accomplishments and future challenges. Journal of Management, 34(6), 1053-1079.

Skocpol, T. (2003). Diminished democracy. From Membership to Management in American Civic Life. Norman: University of Oklahoma Press.

Szekely, G. J., \& Rizzo, M. L. (2005). Hierarchical clustering via joint between-within distances: Extending ward's minimum variance method. Journal of Classification, 22(2), 151-183.

Truman, D. B. (1951). The governmental process. New York: Alfred A. Knopf.

van der Pijl, K., \& Sminia, H. (2004). Strategic management of public interest organizations. VOLUNTAS: International Journal of Voluntary and Nonprofit Organizations, 15(2), 137-155.

Van Deth, J. W., \& Maloney, W. A. (2012). New participatory dimensions in civil society: Professionalization and individualized collective action. London: Routledge.

van Schendelen, R. (2005). Machiavelli in Brussels. The Art of Lobbying the EU. Amsterdam: Amsterdam University Press.

Verhoest, K., Peters, B. G., Bouckaert, G., \& Verschuere, B. (2004). The study of organisational autonomy: A conceptual review. Public Administration and Development, 24(2), 101-118.

Williamson, O. E. (1981). The economics of organization: The transaction cost approach. American Journal of Sociology, 87(3), $548-577$.

Wilson, J. Q. (1995). Political organizations. Princeton: Princeton University Press.

Young, D. R. (1992). Organising principles for international advocacy associations. VOLUNTAS: International Journal of Voluntary and Nonprofit Organizations, 3(1), 1-28. 